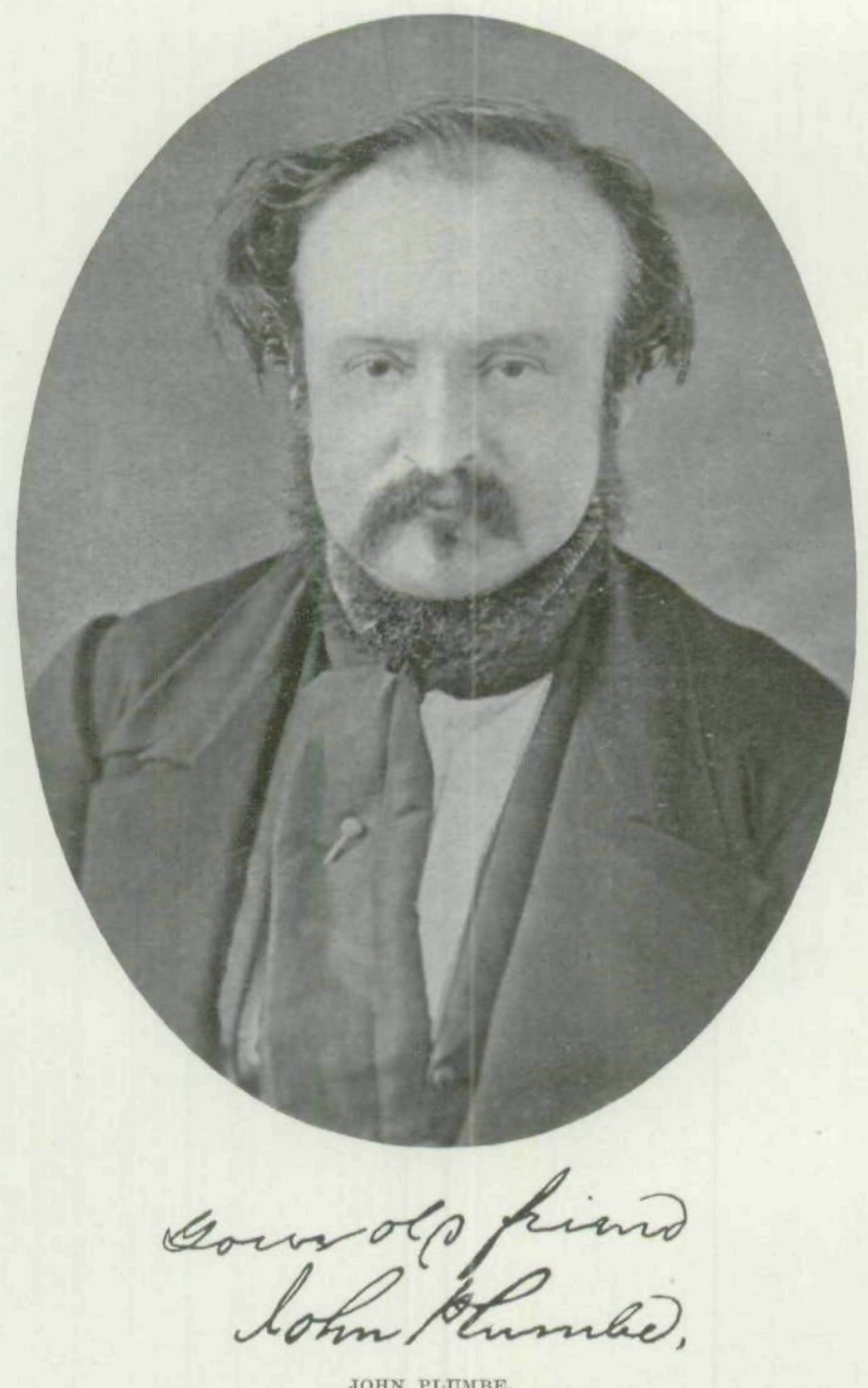

Pioneer resident of Dubuque, Iowa ; civil engineer and originator of the project to build a railroad to the Pacific Ocean. 


\section{JOHN PLUMBE, ORIGINATOR OF THE PACIFIC RAILROAD.}

BY HON. JOHN KING.*

Several statements have appeared in the New York, San Francisco and Dubuque newspapers within three months on the question as to who was the original projector of a railroad from the Atlantic to the Pacific Ocean. Mr. Whitney, Mr. Carver and several others have been named as the first men who laid before the public the plan and the route by which the work has since been almost completed.

I wish to give my testimony on the subject and in behalf of the memory of one of the early citizens of DubuqueJohn Plumbe. Mr. Plumbe came to Dubuque in 1836, and from that time until after 1840, he devoted'a part of his time and considerable money to his cherished purpose of proving that the policy, on the part of the Government, of using a portion of the public domain, of the apparently valueless lands, for the construction of railroads, was the true system of developing the Northwestern States and Territories, and extending civilization to the Rocky Mountains and beyond them.

To those who did not know John Plumbe, I will say that he was a well educated man and a ready writer; that when he came to Dubuque he was an able correspondent of the leading newspapers in New York, Boston, Philadelphia, Baltimore, Washington, Cincinnati and St. Louis; that I have recently examined, in print, the articles from his pen,

*John King was born in Shepardstown, Va., in 1803; he died in Dubuque, Iowa, Feb. 13, 1871. He was the editor and proprietor of The Dubuque Visitor, the first newspaper printed in the territory of Iowa, the initial number of which appeared on the 11th day of May, 1836. The first volume of this pioneer paper is now the property of the Historical Department of Iowa, where it is frequently consulted by students of the history of the times of its publication. After retiring from the newspaper business Judge King continued to write for the local press down to his last illness. The accompanying tribute from his pen to the memory of John Plumbe, with whom originated the idea of a railroad to the Pacific, appeared in the columns of The Dubuque Daily Times in the month of January, 1869.

Vot. VI-19. 
addressed to the papers in the cities named, advocating the building of a railroad from the great lakes to the Mississippi and to Oregon, as an extension of the railroads then commenced westward from the Atlantic coast. I have also carefully examined the volumes of his diary of 1836-7-8-9 and 1840, and find the dates of his personal memoranda to correspond with the printed facts of his newspaper communications and of his memorials to Congress on the same subject in those years.

The first preliminary survey for a railroad from Lake Michigan westward was made by him and mostly at his own expense-a route from Milwaukee to the Mississippi, near Dubuque. He also devoted months of time in the eastern cities trying to convince capitalists and politicians that the great West would soon be the field of the most rapid development, and that all the general government might do to hasten settlements and civilization would soon be repaid a hundred fold by the general prosperity of the whole country.

Mr. Plumbe might have been a little premature, in originating the magnificent conception at so early a day, for the public mind did not seem quite prepared for it, it being too extensive and vast in its proportions, for the majority to regard it favorably. Several citizens of Dubuque, however, with more liberal and expanded views, such as Hon. Geo. W. Jones, Charles Corkery, Dr. Timothy Mason, C. H. Booth, Dr. Lurton, F. Gehon, Dr. Finley, T. S. Wilson, the Langworthy Brothers and others, regarded his ideas with' favor and true appreciation, and did all in their power in the furtherance of the grand project.

As an intimate friend of $\mathrm{Mr}$. Plumbe, knowing that he justly deserves the full credit of being the earliest advocate of this now highly popular and national enterprise, one of the grandest of the 19th century, or indeed of any other age, in its probable results, I respectfully present the facts in the case.

When Mr. Plumbe began to agitate this question in 
1836, the new Territory of Wisconsin in that early day, was considered the Ultima Thule of civilization, but which to an enterprising and energetic mind like his, afforded a wider scope for action than the more contracted field of the older States. In that year, upon seeing the beautiful and almost level prairies of the great West contrasting so strongly with the rugged and difficult surface of the Eastern States, as to the facility for the construction of railroads, his mind at once realized and grasped the idea of the comparative ease of carrying a railroad line across their fertile expanses, between the great lakes and the Mississippi river, to be followed by the extensions to the Missouri and eventually to reach the Pacific Ocean.

This idea he freely and fully canvassed among his friends. And in the winter of 1836-7 I attended a private meeting called by Mr. Plumbe to discuss the railroad question. It was held in a frame building owned at that time by Geo. Strasser, on the west side of Main street, now the property of Mr. Ruff, No. 144. At that meeting Mr. Plumbe advocated, in a conversational way, the feasibility of the construction of a railroad from Milwaukee to Dubuque, as a link by which the lakes would be connected with the Mississippi, and that every successive mile added to the work would be made available as fast as completed. A gentleman who was present subsequently remarked that the project was wild and visionary in the extreme and was but the dream of an enthusiast. In 1837 a more public meeting was called and a speech made on the occasion by Mr. Plumbe. There are several persons now living in Dubuque, besides the writer who were present and participated in the proceedings.

In 1838 he brought forward the idea of an "Oregon Railroad" more forcibly and formally before the public by a personal call for a grand meeting to discuss the subject, which appeared in the "Iowa News," (the successor of the "Visitor,") March 24, 1838. The meeting was accordingly 
held on the 31st of the same month, at which meeting he warmly urged some of its many claims upon the attention of the country.

Resolutions were unanimously adopted at that meeting asking Congress to appropriate funds for the survey and location of the "first permanent link in the great chain of direct steam communication between the extreme east and the far west, which the determined spirit of American enterprise has decreed shall speedily connect the waters of our two opposite oceans." (See original memorial as drawn by John Plumbe, and also one complimentary to the energetic delegate at the time in Congress, Hon. Geo. W. Jones, urging his active co-operation in the matter.) This application to Congress, through the efforts of the delegate, assisted by Senator Linn and others, who took a lively interest in the project, was favorably responded to by an appropriation, expended under the direction of the Secretary of War in making the survey - the report of the engineer in charge being of the most encouraging character. This line was from Milwaukee to Dubuque.

During the winter of $1839-40$, Mr. Plumbe drafted a memorial to Congress urging the importance of continuing the work so auspiciously commenced, which was adopted by the Wisconsin Legislature and then immediately taken by him to Washington, and through the friends of the measure it was urged upon Congress; but owing to the state of the treasury and other pressing subjects then before the government, the application failed of success. The great gold development on the Pacific had not yet occurred, and consequently public sentiment could not yet grasp the bold idea of a continental railroad. In the three succeeding winters of 1841 , ' 42 and ' 43 , he spent much of his time in Washington, watching the progress of events, as connected with his favorite project.

In January, 1847, he wrote and had printed an address, in pamphlet form, and sent a copy to each member of Con- 
gress, urging the importance of setting forth the claims which an early construction of a Railroad to Oregon had upon the public interest and welfare.

On the 26th of March 1847 (the ninth anniversary of the first formal public meeting) a large and respectable number of citizens of Dubuque convened at the Waples House, now the Julien, on which occasion C. H. Booth, Esq., was called to the chair, and Dr. T. Mason was appointed Secretary. At this meeting resolutions were adopted, one of them as follows:

Resolved, Unanimously, that this meeting regards John Plumbe, Esq., as the original projector of the great Oregon Railroad.

On this occasion Mr. Plumbe delivered an able address to those assembled, of considerable length, on the subject, which was highly extolled, and by resolution of the meeting, 5,000 copies of the same were ordered to be printed in pamphlet form, for distribution. He further delivered, in that year, several lectures on the same subject, at Galena, and Bloomington, Ill., Burlington, Iowa, and at various other points in the West at all of which places meetings were held and strong resolutions were adopted in favor of the great enterprise.

In the spring of $1849 \mathrm{Mr}$. Plumbe crossed the plains by way of the South Pass to California, just then the great center of interest. It required nearly a six month's trip, which enabled him to make a very accurate and interesting reconnoissance in reference to a practicable route for a railroad, which his engineering qualifications enabled him to do very satisfactorily; upon which point he has left ample testimony in his voluminous notes and data of the route. His brother, Richard Plumbe, Esq., residing at Plumbeola in this county, and C. Childs, Esq., of this city, have in their possession copies of many of the original articles, published by him in the various public prints of the country at different periods before 1845 , all bearing on his favorite object; but only a small portion of them have been preserved, of 
the hundreds of that character, emanating from his prolific pen.

The writer is well aware that there are many who claim to have been the originators of the idea of a railroad communication with the Pacific. Among them Dr. H. Carver, Hon. T. H. Benton, Asa Whitney, Wilkes \& Co., Degrand and his associates, and probably others; but upon a critical reference to dates and memoranda of their claims, which are all on record, and can be consulted by those who feel an interest in the matter, it is plain to every candid and unbiased mind, that they generally date long subsequent to the inception of the idea by John Plumbe, and also essentially lack as to having been put in any tangible form or shape, as he had so clearly done, at the very outset, and of which, as has been shown by undisputed proof, existing in the published records of the press in the city of Dubuque, and elsewhere, as well as in the memory of living witnesses.

John Plumbe was born in Wales, England, July, 1809, and migrated with the family to the United States in 1821 . After receiving a finished education, he early embraced railroad matters. In the years 1831 and ' 32 he became an assistant under that able and popular R. R. engineer, Moncure Robinson, Esq., of Richmond, Va., in surveying and locating a very difficult route for a track across the Allegheny Mountains, to connect the vast coal and lumber regions of Western Pennsylvania with a canal and railroad system at a point in Huntingdon county, in that state. After a successful termination of this work, he accompanied his principal, Mr. Robinson, to Virginia, in 1832, and through his recommendation was appointed superintendent and manager at its southern extremity of the line of railroad between Richmond and Petersburg, and the termination, at that day, on the Roanoke, in North Carolina, which commanded a very heavy produce and passenger transportation, mails, etc. This line was the earliest railroad enterprise in the States of Virginia and North Carolina. 
After discharging the duties of this responsible position for several years, to the entire satisfaction of his employers, we find him turning his face, in 1836, toward the then new and almost unknown Territory of Wisconsin, then including Iowa, and employing his talents and energy as above stated.

His brother, Richard Plumbe, is a quiet, unassuming gentlemen, of a highly cultivated mind, and is proficient in railroad matters. He was superintendent for a number of years of one of the most prosperous of the railroads in the Southern States. By his integrity to his employers and his genial disposition to the travelling public, he was popular with all classes.

While John Plumbe was in California during the years of 1850 , ' 51 , ' 52 , ' 53 , and ' 54 , he agitated his favorite project by every means in his power; by public meetings and publishing articles on the subject. Thus, up to his death, caused by depression of spirits, acting on a very susceptible mind and nature, he had never relaxed a particle of his fervor and interest in this great undertaking, which cost him and his brother Richard very largely, in a pecuniary point of view, in furtherance of the idea of a Pacific railroad. Indeed, Mr. John Plumbe spent a considerable portion of his life and time in the project, without ever receiving one cent of recompense in any shape or form, not even the recognition of his just right, as originator of this now great national enterprise.

John Plumbe was a very modest man. Even when Whitney succeeded, about $1845-6$, in making a part of the public believe that he originated the idea referred to, Mr. Plumbe made no effort to correct the false impression. To John Plumbe and to Dubuque is due the honor and credit of originating and persistently advocating the great Pacific Railroad policy, years before the subject was taken up by Whitney or any one else.

In fact, Whitney was in Europe when Plumbe was devoting the prime of his life to this great enterprise. Whit- 
ney did not begin his agitation of the question until Plumbe had written and spoken volumes on the subject, and labored for it nearly ten years. The main reason why John Plumbe was not widely known as the ablest writer in the West, on Western interests and Western railroads, was because all his communications were published incog.

The only book he ever published was entitled "Sketches of Iowa and Wisconsin," published in St. Louis in 1839, illustrated by a map of all the then settled part of Iowa. The total population of the Territory was then less than that of Dubuque city at present.

Pardon the writer for thus trespassing on your valuable space. Being aware that considerable interest has been manifested in many portions of the United States as to the question of who the originator of a railroad to the Pacific really was, and at the same time it certainly being honorable to Dubuque, as a city, that one of her worthy early citizens should be truthfully and satisfactorily represented as being justly entitled to the credit; and, besides, feeling an earnest desire to pay a humble though just tribute to the memory of a dear friend-all make the excuse of the writer.

IN THE LONG RUN, then, it depends upon us ourselves, upon us the people as a whole, whether this government is or is not to stand in the future as it has stood in the past, and my faith that it will show no falling off is based upon my faith in the character of our average eitizenship. The one supreme duty is to try to keep this average high. To this end it is well to keep alive the memory of those men who are fit to serve as examples of what is loftiest and best in American citizenship.-President Theodore Roosevelt, at the Dedication of the Sherman Monument. 
Copyright of Annals of Iowa is the property of State of Iowa, by \& through the State Historical Society of Iowa and its content may not be copied or emailed to multiple sites or posted to a listserv without the copyright holder's express written permission. However, users may print, download, or email articles for individual use. 